\title{
Energy cane yield simulated by the DSSAT/CANEGRO model using climate scenarios in Teotônio Vilela, AL, Brazil
}

\author{
Lekson Rodrigues Santos ${ }^{1} \oplus$, Guilherme Bastos Lyra ${ }^{1} \oplus$, André Luiz de Carvalho ${ }^{1 *} \oplus$, José Antônio Bressiani ${ }^{2}$,

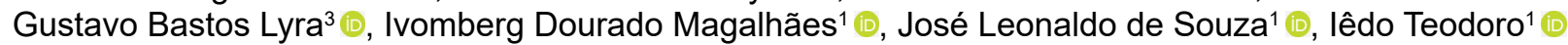

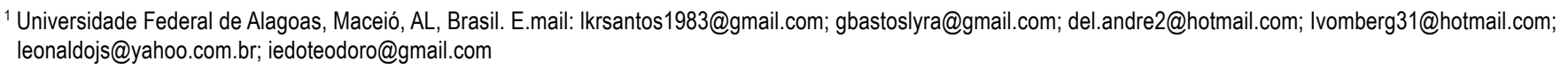

ABSTRACT: Energy cane is a sugarcane variety obtained through genetic improvement and it has higher biomass production, essential for energy generation. Mathematical models for crop forecasts are excellent tools to support crops and can assist in the establishment of energy cane in different environments and in climate change scenarios. The objective of this work was to evaluate the impacts of climate change on energy cane yield simulated by the DSSAT/CANEGRO model in Alagoas, Northeast of Brazil. We used meteorological, crop and soil data from a field experiment conducted in Teotônio Vilela/AL in 2016 and 2017. The energy cane variety used was Vertix 2, cultivated in a plant cane cycle, with planting date on February 4, 2016, and harvesting date on January 31, 2017. Climate projections (2017-2060) were used based on RCPs (2.6, 4.5, 6.0 and 8.5). The model showed high precision and accuracy in simulations with values of 0.98 and 0.94 for fresh matter and 0.99 and 0.88 for dry matter, for $d$ and $r$ indices, respectively. In the RCP 8.5 scenario, the yield reduction may be up to $15 \%$ (fresh matter) and $13.5 \%$ (dry matter) by 2060.

\section{Produtividade de cana energia simulada pelo modelo DSSAT/CANEGRO usando cenários climáticos em Teotônio Vilela, AL, Brasil}

RESUMO: A cana energia é uma variedade de cana-de-açúcar obtida por meio de melhoramento genético e que apresenta maior produção de biomassa, sendo essencial para a geração de energia. Modelos matemáticos para previsões de safras são excelentes ferramentas de apoio às lavouras e podem auxiliar na implantação da cana energia em diferentes ambientes e em cenários de mudanças climáticas. $O$ objetivo deste trabalho foi avaliar os impactos das mudanças climáticas na produção de cana energia simulada pelo modelo DSSAT/CANEGRO em Alagoas, Nordeste do Brasil. Foram utilizados dados meteorológicos, da cultura e de solo de um experimento de campo desenvolvido em Teotônio Vilela/AL em 2016 e 2017. A variedade de cana energia utilizada foi a Vertix 2 e seu cultivo foi no ciclo cana-planta, com plantio realizado em 4 de fevereiro de 2016 e colheita em 31 de janeiro de 2017. As projeções climáticas (2017-2060) foram utilizadas com base nos RCPs (2.6, 4.5, 6.0 e 8.5). O modelo apresentou alta precisão e exatidão nas simulações com valores de 0,98 e 0,94 para a matéria fresca e 0,99 e 0,88 para a matéria seca, para os índices d e r, respectivamente. No cenário RCP8.5, a redução na produtividade pode ser de até 15\% (matéria fresca) e 13,5\% (matéria seca) até 2060. 


\section{Introduction}

Energy cane is a sugarcane variety derived from genetic improvement of wild species (Sarcharum spontaneum and Sarcharum robustum) with commercial hybrids, whose main characteristics are high fiber content, tillering and biomass production (Caversan, 2017). Thus, energy cane is classified as an energy crop, being considered ideal for biofuel, electrical and thermal energy production from its biomass (Silva, 2016). Its rusticity and greater resistance to the attack of pests and diseases enable its cultivation in areas of low agricultural suitability, being combined with the recovery of degraded areas and soil erosion control, in addition to requiring less agricultural inputs (Matsuoka et al., 2014).

Climate change scenarios have promoted greater demand for crops with higher resistance to water deficit and edaphoclimatic adversities. Thus, it is essential to know the implications of climate variations on growth and development of energy cane, in order to improve its yield. For this reason, predictions about future climate, using agrometeorological models, are important to assess the impact of climate change on energy cane yield, in addition to assisting in decision making on production management strategies (Silva, 2012; Jones \& Singels, 2018).

The use of mathematical models for crop forecasting is useful to generate information regarding energy cane cultivation in future climate scenarios. These crop models are used to study the effects and interactions of environmental conditions, in addition to allowing the simulation of scenarios under different soil and atmosphere conditions, and also to assist in the planning of irrigation and other agricultural practices (Singels et al., 2008).

Currently, the crop model most used for the cultivation of sugarcane varieties is DSSAT (Decision Support System for Agrotechnology Transfer) (Singels et al., 2008). DSSAT/ CANEGRO has been used in several locations around the world, making production analyses for sugarcane cultivation more agile and effective (Marin et al., 2011). For this, the DSSAT/CANEGRO model calibration must be performed with experimental data in order to obtain better performance in the simulations. In Brazil, the DSSAT/CANEGRO model was used to simulate production and growth variables for sugarcane varieties in São Paulo (Jones et al., 2015) and to analyze the impacts of climate change on sugarcane yield (Silva, 2012; Marin et al., 2013).

According to the Global Climate Models (GCMs) projections, climate change may benefit sugarcane, with increased yield, due to its greater resistance to high temperatures, until its limit to water and thermal stress is reached (Carvalho et al., 2015). However, studies involving impacts of climate change and energy cane are still scarce. Future climate projections are based on reports released by the IPCC (Intergovernmental Panel on Climate Change), which indicate climate vulnerability according to the socioeconomic development for each location, using the RCPs (Representative Concentration Pathways) (Oliveira, 2015).
Therefore, the objective of this research was to evaluate the impacts of climate change on energy cane yield simulated by the DSSAT/CANEGRO model in the region of Coastal Tablelands in the Alagoas state, Northeast of Brazil.

\section{Materials and Methods}

\section{Study location and obtaining of meteorological data}

The research was conducted in an experimental area of GranBio company, with approximately 1.0 ha, located at Fazenda Rocheira, in Teotônio Vilela city, state of Alagoas (095'35" S; 36 17'03" W; 124 m), Northeast Brazil. The region's climate, according to Thornthwaite climate classification, is megathermal ( $\left.A^{\prime}\right)$ dry sub-humid (C1), with little or no excess water (d), and a concentration of $41.5 \%$ of the reference evapotranspiration ( $\mathrm{ET}_{0}$ ) from December to March. The total annual rainfall is $1,076 \mathrm{~mm}$, with a concentration of $58 \%$ in April to July and poor water distribution throughout the year. During this period, the lowest temperatures occur and, consequently, the lowest reference evapotranspiration, while in the other months the opposite occurs (Sarmento, 2019).

Meteorological data (global solar radiation, rainfall, air temperature (maximum and minimum), relative humidity and wind speed) were obtained from an automatic agrometeorological station (Micrologger CR10X, Campbell Sci., Logan, Utah) of the Laboratory of Agrometeorology and Solar Radiometry at the Federal University of Alagoas (LARAS - UFAL), located in the experimental area.

\section{Field experiment}

\section{Experimental design and treatments}

The experimental design was in randomized blocks with three replications, in which the treatments were twentythree genotypes of energy cane and another genotype of sugarcane. However, only seven sugarcane genotypes and one commercial sugarcane genotype (RB92579) were evaluated in the experiment. The research gave priority to the sugarcane genotypes of Vertix, from GranBio's genetic improvement program, and the RB92579 sugarcane variety, for showing excellent agronomic performance in the Northeast (Agrolink, 2019). The plots consisted of six 10-meter-long rows. To perform the modeling on the DSSAT/CANEGRO platform, genotype VX12-1744 was selected, registered as Vertix 2 variety (Boschiero et al., 2018) at the Ministry of Agriculture, Livestock and Food Supply.

The irrigation method used was sprinkling, according to the design water depth of the GranBio farm, using the mobile linear displacement irrigation system, which was $60 \mathrm{~mm}$, in a 15-day interval, applying $120 \mathrm{~mm}$ monthly.

\section{Planting and crop management}

Planting was carried out on February 04, 2016, with presprouted seedlings (MPB), which were propagated asexually by means of buds arranged in tubes with substrate. The transplant occurred when the seedlings were more than 45 
days after planting (DAP). The spacing was $0.70 \mathrm{~m}$ between plants, alternating between 0.90 and $1.50 \mathrm{~m}$ between rows. Basal fertilization was carried out in the planting furrow with $50 \mathrm{~kg} \mathrm{ha}^{-1}$ of nitrogen, plus $150 \mathrm{~kg} \mathrm{ha}^{-1}$ of $\mathrm{P}_{2} \mathrm{O}_{5}$ and $50 \mathrm{~kg} \mathrm{ha}^{-1}$ of $\mathrm{K}_{2} \mathrm{O}$. For weed control, $1,440 \mathrm{~g} \mathrm{ha}^{-1}$ of the active ingredient of Metribuzin plus $120 \mathrm{~g} \mathrm{ha}^{-1}$ of the active ingredient of Mesotrione were applied. Harvest was carried out on January 31, 2017.

\section{Plant growth and development analysis}

Growth analyses were performed monthly from ten plants marked on the two central rows of each plot. The growth variables analyzed were: Plant height, leaf area index (LAI), stalk diameter, tillering and dry biomass. The assessments to determine dry biomass were destructive, based on the collection of three clumps per plot. The plant material was kept in a forced ventilation oven at $65{ }^{\circ} \mathrm{C}$ until the mass had a constant value (Sarmento, 2019; Silva, 2019).

Leaf area was measured using the device LAI-2000, and LAI was calculated using the ratio between leaf area and the area occupied by the plants (Sousa et al., 2015; Sarmento, 2019). The crop cycle was divided into four phenological stages (Table 1$)$. The reference evapotranspiration $\left(\mathrm{ET}_{0}, \mathrm{~mm}\right)$ was calculated by the parameterized Penman-Monteith method for a hypothetical crop according to FAO bulletin no. 56 - Food and Agriculture Organization (Allen et al., 1998). The crop evapotranspiration (ETc, $\mathrm{mm}$ ) was determined by the product between $\mathrm{ET}_{0}$ and crop coefficient $(\mathrm{Kc})$, in which the $\mathrm{Kc}$ was determined according to the single-Kc method proposed in the FAO 56 bulletin. The Kc values were adjusted according to the weather conditions of the place and crop (initial Kc: 0.40; intermediate Kc: 1.25; final Kc: 0.75) (Allen et al., 1998).

\section{Production variables}

The energy cane biomass production was evaluated bimonthly and at the final harvest of the experiment. Tons of green mass per hectare, tons of dry mass per hectare and agro-industrial variables such as ${ }^{\circ}$ Brix, percentage of fiber, total reducing sugars and total recovered sugars were evaluated. These variables were determined from 300 grams of green biomass crushed in a forage chopper, according to the methodology described by Sarmento (2019).

\section{DSSAT/CANEGRO model}

\section{Model parameterization}

Energy cane growth and development variables were simulated using the CANEGRO model, which is included in the DSSAT system (Singels et al., 2008). For DSSAT/CANEGRO model parameterization, meteorological data were inserted in the climate file, such as: global solar radiation $\left(\mathrm{W} \mathrm{m}^{-2}\right)$, maximum and minimum air temperature $\left({ }^{\circ} \mathrm{C}\right)$, rainfall $(\mathrm{mm})$, wind speed $\left(\mathrm{m} \mathrm{s}^{-1}\right)$ and air humidity (\%). The data used for the soil file were: texture (sand, silt and clay), density and $\mathrm{pH}$ of the study area. In addition, the model also requires data that regulate the physical-hydraulic soil properties, such as soil moisture at field capacity, permanent wilting point and saturation, in addition to the depth of the soil. Crop management data (variety, row spacing, plant population and information on the amount and date of irrigation and fertilization) were also used.

This model is based on sugarcane growth and development modeling processes, which include phenology, canopy growth, biomass and sucrose accumulation, partition, root growth, water stress and lodging (Singels et al., 2008; Nassif et al., 2012).

\section{Calibration of the DSSAT/CANEGRO model for energy cane} genetic parameters

The model was adjusted by changes in specific parameters related to sugarcane crop (Table 2), from a standard variety (NCo-376) previously calibrated in the DSSAT/CANEGRO model as suggested by Singels et al. (2008).

Genetic parameters for the standard cultivar of the DSSAT/CANEGRO model are relevant for both plant cane and ratoon cane. The adjustments were made manually, based on the characteristics expressed by the Vertix 2 sugarcane genotype in the field. First, the crop parameters related to the phenology and growth (TTHALFO, TBASE, LFMAX, MXLFAREA, MXEFARNO, PI1, PI2, PSWITCH, TTPLNTEM, CHUPIBASE, TT_POPGROWTH, MAX_POP, POPTTI6) were adjusted and, later, the parameters related to yield (PARCEMAX, APFMX, STKPFMAX, SUCA, TBFT, LG_AMBASE).

\section{DSSAT/CANEGRO model evaluation}

For statistical evaluation of the DSSAT/CANEGRO model performance, the Wilmott's Index of Agreement (d), the Root Mean Square Error (RMSE), the Coefficient of Determination of the linear regression $\left(R^{2}\right)$ and Pearson's Correlation Coefficient ( $r$ ) between observed and simulated variables were used. The variables evaluated were: fresh and dry matter, leaf area index, stalk height and tillering.

\section{Climate scenarios}

Climate projections that comprise the present climate (1961-1990) and future climate (2017-2060) were obtained using the Eta-MIROC5 Regional Climate Model (RCM) and the Marksim DSSAT Weather File Generator software (gismap. ciat.cgiar.org/Marksim). Climate projections in Eta-MIROC5 were carried out using four RCPs: RCP2.6, RCP4.5, RCP6.0 and RCP8.5. In the Fifth Assessment Report - AR5 (2013), RCPs represent representative $\mathrm{CO}_{2}$ concentration pathways

Table 1. Crop coefficient for energy cane according to DAT.

\begin{tabular}{cccccc}
\hline Stage/Period & I & II & III & IV & Total \\
\hline Stage start & $02 / 04 / 2016$ & $03 / 25 / 2016$ & $06 / 03 / 2016$ & $01 / 08 / 2017$ & 26 \\
Period (days) & 50 & 70 & 220 & 366 \\
\hline
\end{tabular}

Stage I - initial; Stage II - growth; Stage III - development and Stage IV - final. 
Table 2. Input parameters of the DSSAT/CANEGRO model for energy cane.

\begin{tabular}{|c|c|c|c|c|}
\hline Parameters & Descriptions & Units & NCo-376 & Vertix 2 \\
\hline PARCEMAX & $\begin{array}{l}\text { Maximum (no stress) radiation conversion efficiency } \\
\text { expressed as assimilate produced before respiration, } \\
\text { per unit of PAR. }\end{array}$ & $\mathrm{g} \mathrm{MJ}^{-1}$ & 9.90 & 30.90 \\
\hline APFMX & $\begin{array}{l}\text { Maximum fraction of dry mass increments that can } \\
\text { be allocated to aerial dry mass. }\end{array}$ & $\mathrm{Mg} \mathrm{Mg}^{-1}$ & 0.88 & 0.90 \\
\hline STKPFMAX & $\begin{array}{l}\text { Fraction of daily aerial dry mass increments } \\
\text { partitioned to stalk at high temperatures in a } \\
\text { mature crop. }\end{array}$ & $\mathrm{Mg} \mathrm{Mg}^{-1}$ & 0.65 & 0.65 \\
\hline SUCA & Maximum sucrose contents in the base of stalk. & $\mathrm{Mg} \mathrm{Mg}^{-1}$ & 0.58 & 0.58 \\
\hline TBFT & $\begin{array}{l}\text { Temperature at which partitioning of unstressed } \\
\text { stalk mass increments to sucrose is } 50 \% \text { of the } \\
\text { maximum value. }\end{array}$ & ${ }^{\circ} \mathrm{C}$ & 25 & 25 \\
\hline TTHALFO & Thermal time to half canopy. & ${ }^{\circ} \mathrm{C} \mathrm{d}$ & 250 & 250 \\
\hline TBASE & Base temperature for canopy development. & ${ }^{\circ} \mathrm{C}$ & 16 & 16 \\
\hline LFMAX & $\begin{array}{l}\text { Maximum number of green leaves a healthy, } \\
\text { adequately-watered plant will have after it is old } \\
\text { enough to lose some leaves. }\end{array}$ & Leaf & 12 & 11 \\
\hline MXLFAREA & $\begin{array}{l}\text { Maximum leaf area assigned to all leaves above leaf } \\
\text { number MXLFArno. }\end{array}$ & $\mathrm{cm}^{2}$ & 360 & 380 \\
\hline MXEFARNO & $\begin{array}{l}\text { Leaf number above which leaf area is limited to } \\
\text { MXLFArea. }\end{array}$ & Leaf & 15 & 15 \\
\hline $\mathrm{Pl}_{1}$ & $\begin{array}{l}\text { Phyllocron interval } 1 \text { for leaf numbers below } \\
\text { Pswitch. }\end{array}$ & ${ }^{\circ} \mathrm{C} d$ & 69 & 120 \\
\hline $\mathrm{Pl}_{2}$ & $\begin{array}{l}\text { Phyllocron interval } 2 \text { for leaf numbers above } \\
\text { Pswitch. }\end{array}$ & ${ }^{\circ} \mathrm{C} d$ & 169 & 169 \\
\hline PSWITCH & Leaf number at which the phyllocron changes. & Leaf & 18 & 18 \\
\hline TTPLNTEM & Thermal time to emergence for a plant crop. & ${ }^{\circ} \mathrm{C} d$ & 428 & 950 \\
\hline TTRATNEM & Thermal time to emergence for a ratoon crop. & ${ }^{\circ} \mathrm{C} d$ & 203 & 203 \\
\hline CHUPIBASE & $\begin{array}{l}\text { Thermal time from emergence to start of stalk } \\
\text { growth. }\end{array}$ & ${ }^{\circ} \mathrm{C} d$ & 1,050 & 1,050 \\
\hline TT_POPGROWTH & Thermal time to peak tiller population. & ${ }^{\circ} \mathrm{C} \mathrm{d}$ & 600 & 900 \\
\hline MAX_POP & Maximum tiller population. & Stalks $\mathrm{m}^{-2}$ & 30 & 27 \\
\hline POPTTI6 & Stalk population at/after $1600^{\circ} \mathrm{C} \mathrm{d}^{-1}$ & Stalks $\mathrm{m}^{-2}$ & 13.3 & 18.58 \\
\hline LG_AMBASE & $\begin{array}{l}\text { Aerial mass (fresh mass of stalks, leaves, and } \\
\text { moisture) at which lodging start. }\end{array}$ & $\mathrm{Mg} \mathrm{ha}^{-1}$ & 220 & 220 \\
\hline
\end{tabular}

for the total radiative forcing until 2100: $\mathrm{RCP2} .6=2.6 \mathrm{~W} \mathrm{~m}^{-2}$; $\mathrm{RCP} 4.5=4.5 \mathrm{~W} \mathrm{~m}^{-2} ; \mathrm{RCP} 6.0=6.0 \mathrm{~W} \mathrm{~m}^{-2} ;$ and RCP8.5 $=8.5 \mathrm{~W}$ $\mathrm{m}^{-2}$. RCPs are climate scenarios with projections for the future radiative forcing gas emission rates and mitigation efforts. RCP2.6 is the most optimistic scenario, which reaches its peak in the middle of the 21st century. RCP4.5 and RCP6.0 are a continuation of the current emissions pathway, which reaches a global radiative forcing until the year 2100. For RCP8.5, the heating is designed to extend beyond 2100 in all scenarios, with the exception of RCP2.6, with the radiative forcing of $8.5 \mathrm{~W} \mathrm{~m}^{-2}$ more than pre-industrial levels. Each RCP provides spatially distributed data sets on land use changes and sectoral emissions of air pollutants and specifies the annual concentrations of greenhouse gases up to the year 2100 .

\section{Results and Discussion}

\section{DSSAT/CANEGRO model calibration \\ Production variables}

Measured and simulated biomass (fresh and dry matter) of energy cane are shown in Figure 1. It was observed that, in general, the model tended to overestimate and underestimate, respectively, the fresh and dry matter values during its cultivation cycle. Anyway, in both simulations satisfactory representations were obtained in the variation curve of these variables. The final values of fresh and dry matter simulated by the DSSAT/CANEGRO model were 165,000 and $46,500 \mathrm{~kg}$ $\mathrm{ha}^{-1}$, which differed from the observed values by $18.7 \%$ and $3.3 \%$, respectively. Fresh and dry matter simulations using the DSSAT/CANEGRO model obtained a high degree of fit to observed data in the field, indicating simulation precision, with $\mathrm{R}^{2}$ equal to 0.94 and 0.88 for fresh and dry matter, respectively (Table 3 ).

Studies involving the simulation of energy cane are scarce or nonexistent. However, several studies address the simulations of sugarcane varieties by agrometeorological models. Nassif et al. (2012) obtained reasonable fits in simulations for fresh matter of the RB86-7515 sugarcane variety $\left(d=0.74, R^{2}=0.51\right.$ and $\mathrm{RMSE}=30,300 \mathrm{~kg} \mathrm{ha}^{-1}$ ). Marin et al. (2011) obtained good results for dry matter of RB72454 (RMSE $=9,800 \mathrm{~kg} \mathrm{ha}^{-1}$ ) and SP83-2847 (RSME = 9,600 kg ha-1) varieties. 

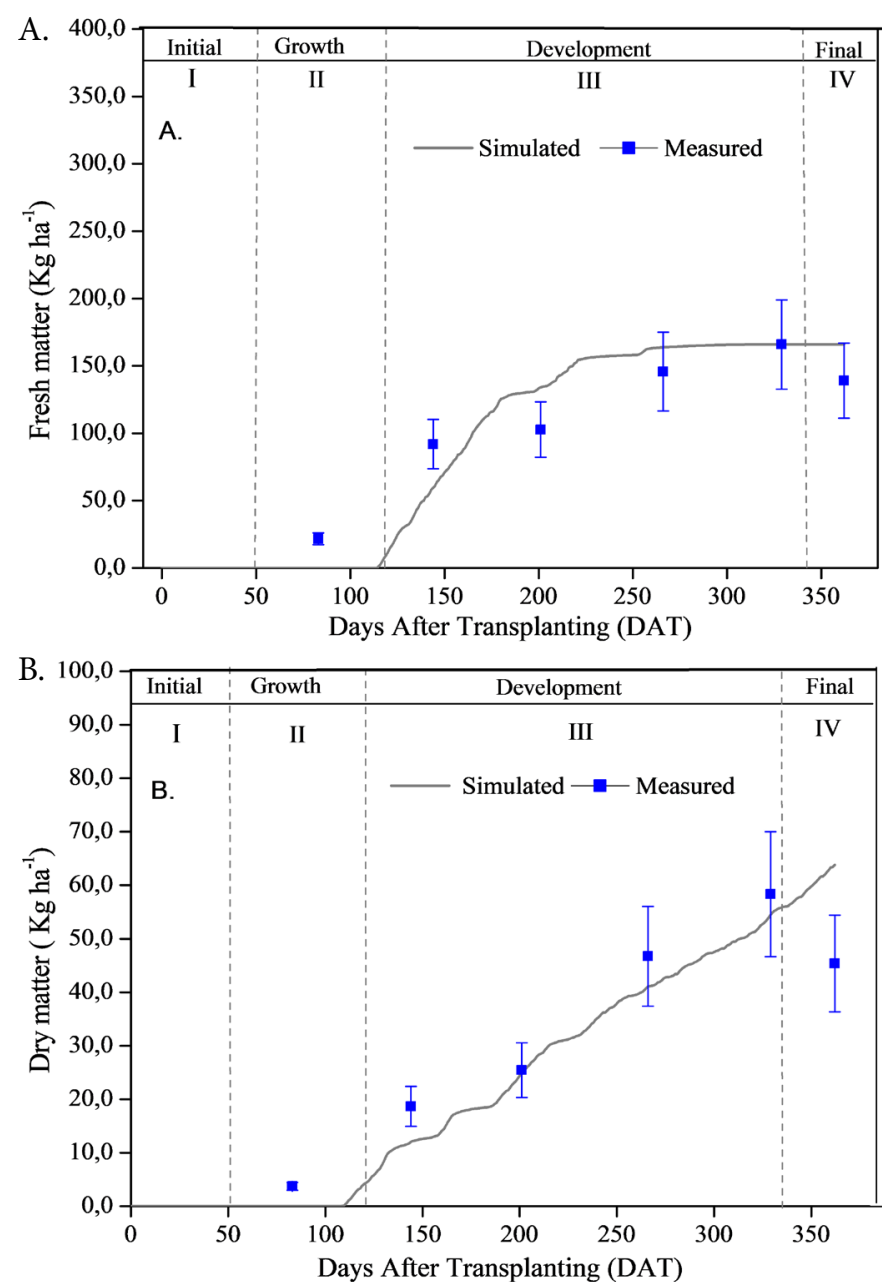

Figure 1. Measured and simulated fresh (A) and dry (B) matter throughout the crop cycle.

Table 3. Statistical indices: Coefficient of Determination $\left(R^{2}\right)$, Willmott's Index of Agreement (d), Root Mean Square Error (RMSE) and Pearson's Correlation Coefficient ( $r$ ) for production and growth variables of an energy cane variety.

\begin{tabular}{lcccc}
\hline & $\mathbf{R}^{\mathbf{2}}$ & $\mathbf{d}$ & $\mathrm{RMSE}$ & $\mathbf{r}$ \\
\hline Production variables & & & & \\
Fresh matter & 0.94 & 0.98 & 24.37 & 0.94 \\
Dry matter & 0.88 & 0.99 & 10.27 & 0.88 \\
\hline Growth variables & & & & \\
Leaf Area Index & 0.72 & 0.99 & 1.66 & 0.72 \\
Stem height & 0.98 & 0.99 & 0.94 & 0.98 \\
Tillering & 0.75 & 0.99 & 5.77 & -0.75 \\
\hline
\end{tabular}

\section{Growth variables}

Measured and simulated Leaf Area Index (LAI) of energy cane are shown in Figure 2. In general, the model tended to underestimate the LAI during almost its entire growing cycle. The final value of LAI simulated by the Century model was $2.95 \mathrm{~m}^{2} \mathrm{~m}^{-2}$, which represented errors of $2.4 \%$. In general, it was observed that there was a good correlation between the observed and simulated data, with $R^{2}$ equal to 0.72 (Table 3 ).

Sugarcane LAI was analyzed by Silva (2012), who observed a limitation in the parameterization of this variable for RB92579 sugarcane variety. Marin et al. (2009) suggest that

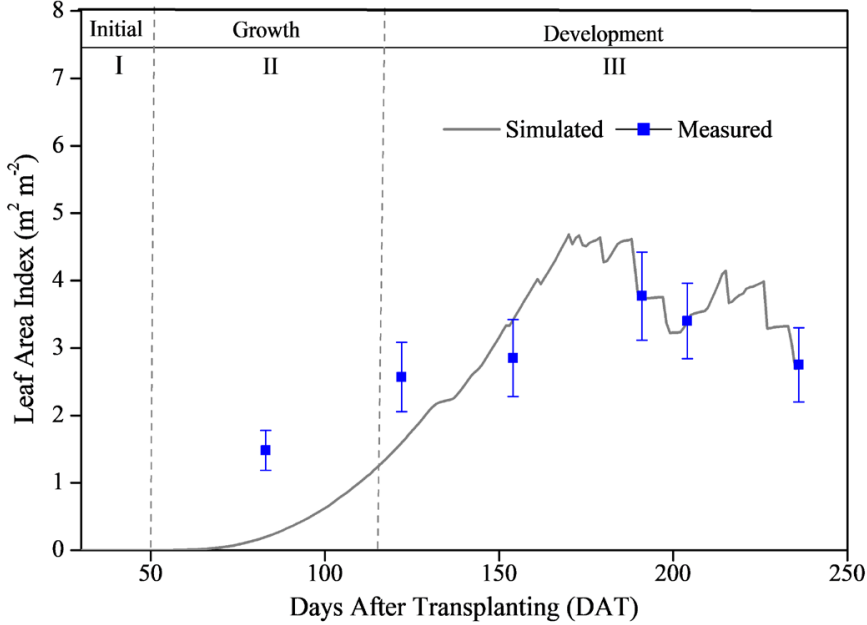

Figure 2. Measured and simulated Leaf Area Index $\left(\mathrm{m}^{2} \mathrm{~m}^{-2}\right)$ throughout the crop cycle.

further studies are needed to better fit this variable in the DSSAT/CANEGRO model.

Measured and simulated stalk height for energy cane are shown in Figure 3. In general, the model underestimated the stalk growth throughout its cultivation cycle. Despite this, the model managed to represent the variation curve of stalk height, indicating a high degree of fit between the observed and simulated data in the statistical indices (Table 3 ), with $R^{2}$ equal to 0.98 . The maximum stalk height simulated by the DSSAT/ CANEGRO model was $2.65 \mathrm{~m}$, with an error of $-25.6 \%$. This result may indicate systematic error and, therefore, the need to improve the representativeness of the parameters related to this variable.

Nassif et al. (2012) obtained stalk height results for CTC7 $(d=0.80 ; \mathrm{RMSE}=0.48 ; \mathrm{R} 2=0.94)$ and CTC20 $(d=0.81 ; \mathrm{RMSE}$ $=0.63 ; R^{2}=0.92$ ) sugarcane varieties, also indicating a good degree of fit of the model with these varieties in comparison to the observed data.

Measured and simulated tillering of energy cane are shown in Figure 4. The tillering did not show typical behavior of sugarcane varieties (it reaches its maximum peak, decreases

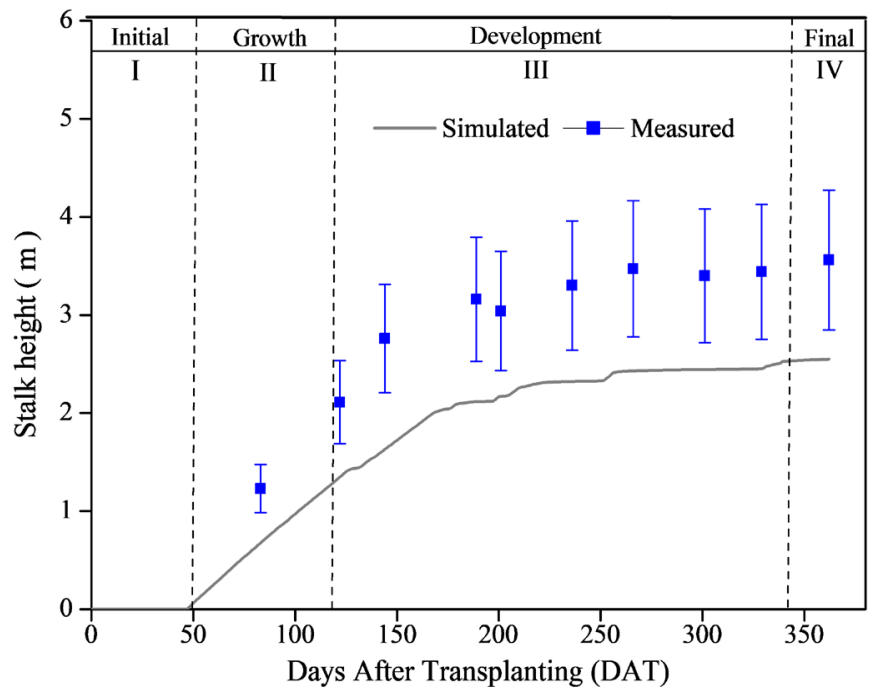

Figure 3. Measured and simulated stalk height throughout the crop cycle. 


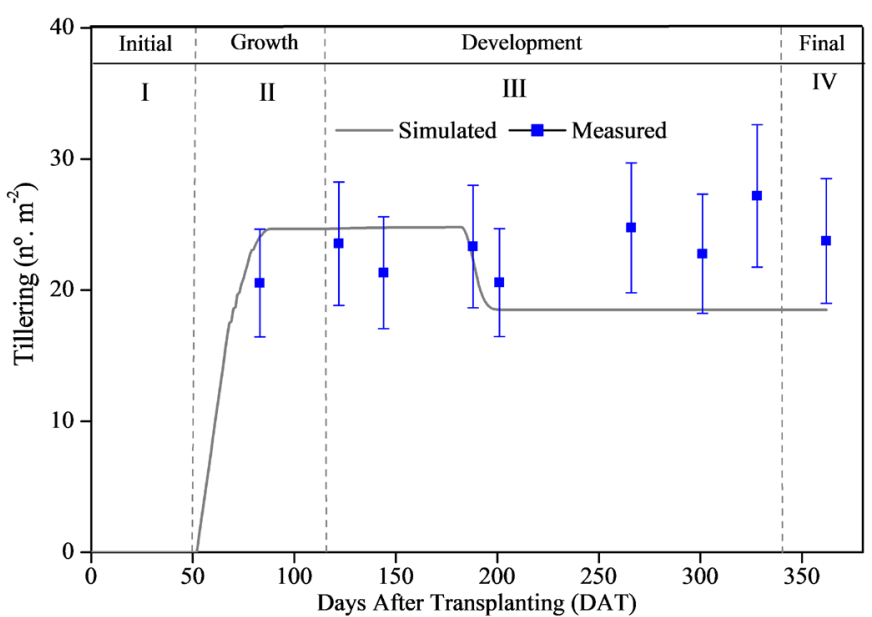

Figure 4. Measured and simulated tillering throughout the crop cycle.

and stabilizes). This atypical behavior for energy cane may be due to the fact that it has rhizomes, which implies plants that sprout faster, with denser tillering. Sugarcane in its early days had this characteristic (rhizomes), but in the last 100 years, breeding programs have concentrated only on varieties with a higher content of sucrose, and this rhizome characteristic has been reduced (Matsuoka et al., 2012). The final simulated value of tillering of the energy cane was 18.5 stalks $\mathrm{m}^{-2}$, with an error of $-21.3 \%$. In general, the statistical indices showed similarity between the observed and simulated data (Table 3), with $R^{2}$ equal to 0.75 . The DSSAT/CANEGRO model encountered some difficulties in the analysis of tillering, requiring more evaluations for energy cane genotypes.

Nassif et al. (2012), in a study on tillering with the RB867515 sugarcane variety, obtained satisfactory results (d $=0.873$ and $\left.R^{2}=0.57\right)$.

\section{Water balance analysis}

The DSSAT/CANEGRO model was also used to simulate the transpiration and accumulated evaporation for energy cane (Figure 5). Initially, the evaporation was greater than the transpiration due to the slow growth of the leaf area of the energy cane, but the accumulated total of transpiration was greater. The model performed well in the crop evapotranspiration (ETc) simulations, with a simulated ETc of 1,367 $\mathrm{mm}$ and observed ETc of $1,080 \mathrm{~mm}$, a difference of $26.6 \%$, with the E/ETc ratio being $60.9 \%$ and T/ETc was $39.1 \%$. These values were lower than those found by Carvalho et al. (2017) with RB93509 sugarcane variety in plant cane and ratoon, in an experiment conducted by Almeida et al. (2008) in Rio Largo, Alagoas, in which the E/ETr ratio was $44 \%$ in the plant cane and $32 \%$ in ratoon and the $\mathrm{T} / \mathrm{ETr}$ ratio was $56 \%$ in the plant cane and $68 \%$ in the first ratoon cycle. The E/ETc ratio was $32 \%$ in the plant cane and $20 \%$ in the ratoon and T/ ETC was $42 \%$ in the plant cane and $42 \%$ in ratoon.

\section{Energy cane yield in climate change scenarios}

Prediction correlation made in DSSAT/CANEGRO using meteorological data observed and meteorological data from MIROC5

The need to use meteorological data from the MIROC5 model is due to the greater precision in the analysis and

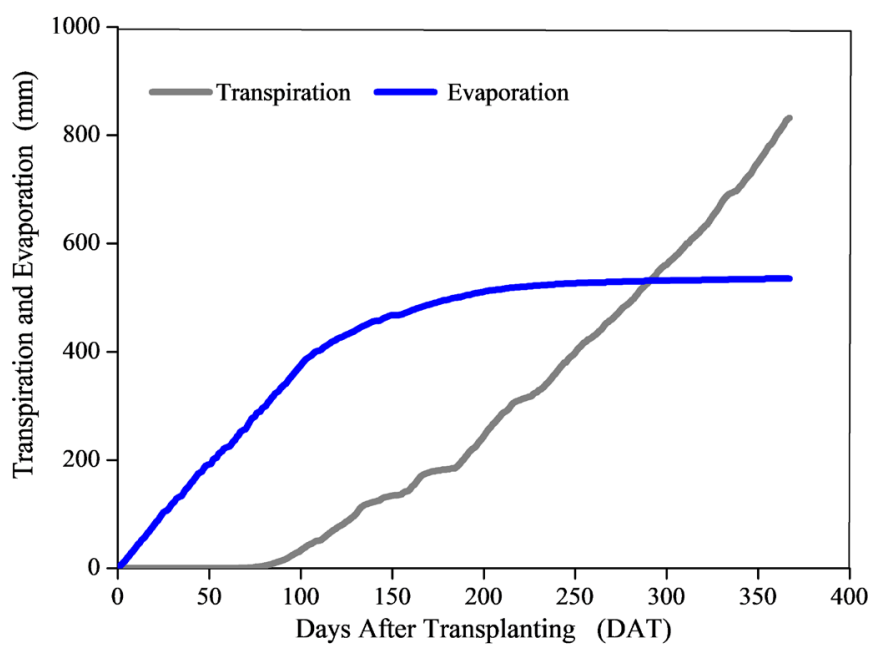

Figure 5. Accumulated transpiration $(\mathrm{T} ; \mathrm{mm}$ ) and evaporation (E; $\mathrm{mm}$ ) simulated by the DSSAT / CANEGRO model for energy cane, in the state of Alagoas.

representativeness in the DSSAT/CANEGRO model, making the simulations for the present and future scenarios more accurate (Guimarães et al., 2016). Thus, it was necessary to carry out an evaluation on obtained data based on the climate scenarios simulated by MIROC5. In Figure 6, the correlation of fresh and dry matter simulation data was observed using meteorological data measured and obtained in the climate scenarios simulated by the MIROC5 model for RCPs 2.6, 4.5, 6.0 and 8.5.

There was a high correlation for simulated fresh and dry matter with measured and simulated data by the MIROC5 model. The correlations for fresh matter showed a high $\mathrm{R}^{2}$ value, ranging from 0.92 to 0.94 in all RCPs. The good results observed in the correlations between the yield of fresh and dry matter with measured and simulated data provided support for the simulations in the future period to be made.

\section{Impacts of climate change on energy cane yield}

The values of observed fresh and dry matter in the field were 138,000 and $45,000 \mathrm{~kg} \mathrm{ha}^{-1}$, respectively. Yield projections of fresh and dry matter of energy cane can be seen in Figure 7. The simulations carried out for the fresh and dry matter variables of the current scenario (2017) obtained values of 145,000 and $41,000 \mathrm{~kg} \mathrm{ha}^{-1}, 135,000$ and $38,000 \mathrm{~kg} \mathrm{ha}$ ${ }^{1}, 136,000$ and $38,000 \mathrm{~kg} \mathrm{ha}^{-1}$, and 133,000 and $37,000 \mathrm{~kg} \mathrm{ha}^{-1}$, respectively for RCPs 2.6, 4.5, 6.0 and 8.5, with model errors below $20 \%$ (Figure 7 ).

In the projections, all RCPs showed an increase in yield (fresh and dry matter) up to the year 2060, with the exception of the RCP8.5 scenario in which yield started to decrease after 2037. Comparing the yield of energy cane for the current period (2017) with those projected for 2060, the increase in yield was greater in RCP6.0, with 160,000 and $45,000 \mathrm{~kg} \mathrm{ha}^{-1}$, increases of $24,000 \mathrm{~kg} \mathrm{ha}^{-1}$ $(17.7 \%)$ and $7,000 \mathrm{~kg} \mathrm{ha}^{-1}(18.6 \%)$. In RCP8.5, increased energy cane yield in the first years of the projection was 

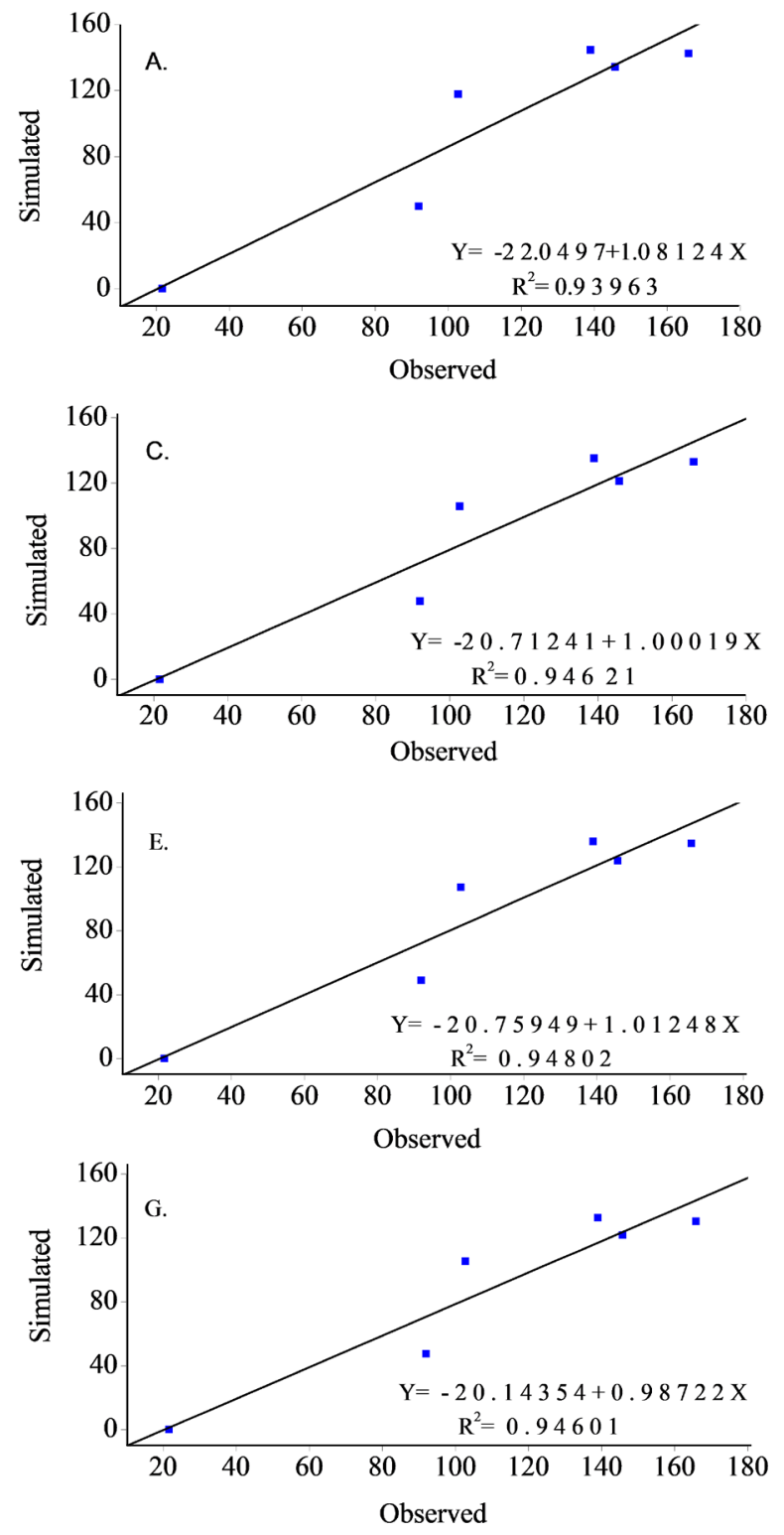
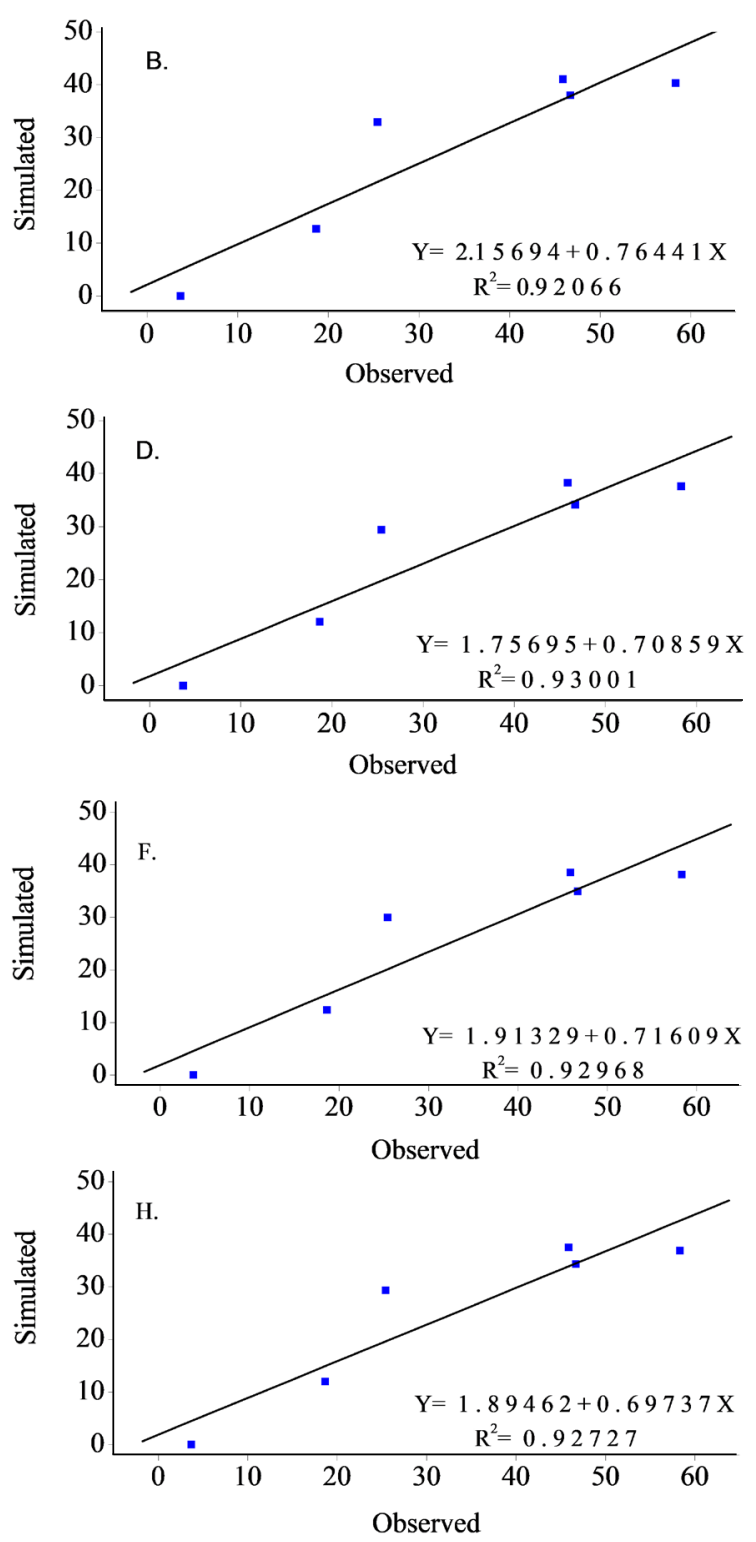

Figure 6. Correlation between fresh (LEFT) and dry matter (RIGHT) for meteorological data observed in the field (X AXIS) and those simulated by DSSAT/CANEGRO (Y AXIS) using climate scenarios of the MIROC5 model, for RCPs 2.6 (a, b), 4.5 (c, d), 6.0 (e, f) and $8.5(\mathrm{~g}, \mathrm{~h})$ for the present period (2016-2017).

observed, reaching values of 146,000 and $41,000 \mathrm{~kg} \mathrm{ha}^{-1}$ in 2036, that is, increases of $9.8 \%$ and $10.7 \%$. However, from that year on, the yield of sugarcane began to decrease, probably due to the high temperatures projected in RCP8.5, which reach a maximum increase of $4.0^{\circ} \mathrm{C}$ (Guimarães et al., 2016), showing that the sugarcane was sensitive to the gradual increase in temperature. Thus, the yields of energy cane were 113,000 and $32,000 \mathrm{~kg} \mathrm{ha}^{-1}$ in 2060 , and thus reductions of $15 \%$ and $13.5 \%$, respectively for fresh and dry matter, compared to 2017.

These results show that sugarcane can benefit from climate change due to the increase in air temperature. Thus, its cultivation may be expanded to areas where there are restrictions due to low temperatures, expanding its area suitable for planting to the southeastern and southern regions of the country. The increase in temperature and $\mathrm{CO}_{2}$ emissions can promote an increase in sugarcane yield, due to the increase in efficiency in the photosynthesis process, a fact observed until the plant reaches its tolerance to climatic conditions and, with this, shows a reduction of yield (Carvalho et al., 2015). This is the explanation for yield reduction of energy cane in the scenario RCP8.5, in which the increase close to $4.0^{\circ} \mathrm{C}$ in the air temperature may have reached the maximum tolerance of the plant, causing thermal stress. Pinto et al. (2018) stated that the projections used indicated an increase in yield (RB867515 sugarcane variety) in the state of São Paulo simulated based on climate scenarios RCPs by the APSIM-Sugar and DSSAT/CANEGRO models on three different harvest dates. Marin et al. (2015) stated that there was an increase in the growth of sugarcane (RB867515 sugarcane variety) under conditions of increased rainfall and simulated $\mathrm{CO}_{2}$ concentration in several locations across the country 

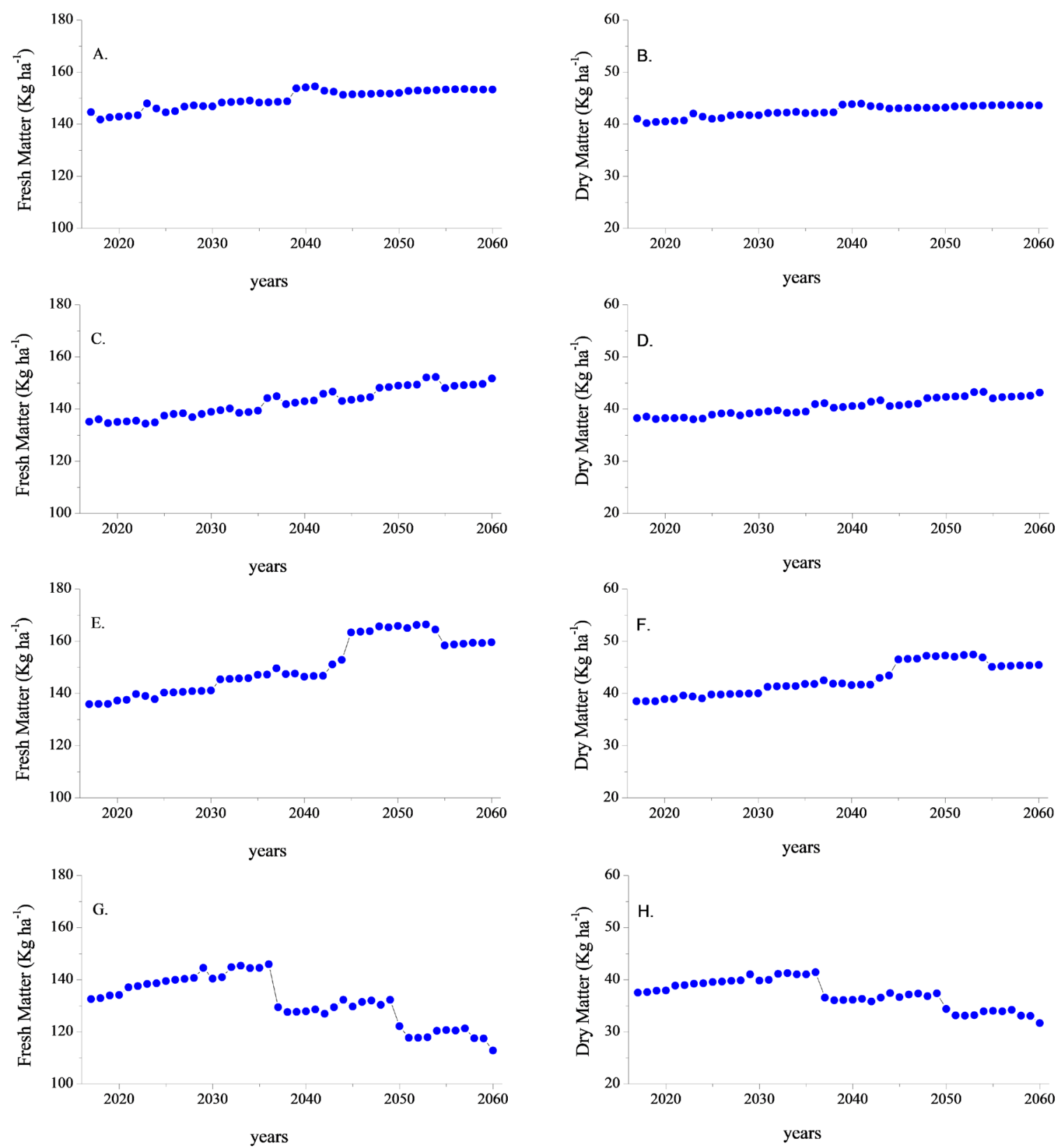

Figure 7. Projections of fresh (LEFT) and dry (RIGHT) matter of energy cane for RCPs $2.6(a, b), 4.5$ (c, d), 6.0 (e, f) and 8.5 (g, h), for the period of 2017-2060, in the region of Teotônio Vilela-AL, Brazil.

using the DSSAT/CANEGRO and APSIM models, but its growth was limited by the increase temperature $\left(+6.0^{\circ} \mathrm{C}\right)$, impacting its yield.

\section{Conclusions}

The DSSAT/CANEGRO model satisfactorily simulates growth and development parameters of energy cane, from a variety of sugarcane inserted in the model. The yield of fresh and dry matter is satisfactorily reproduced by the model with errors of less than $20 \%$, which shows that the model is capable of carrying out simulations and projections for the future climate.

Energy cane may have an increase in yield due to climate changes, in the RCPs scenarios (2.6, 4.5 and 6.0), due to the increase in air temperature until 2060. In the RCP6.0 scenario, the maximum increase in yield may be up to $17.7 \%$ and $18.6 \%$ by 2060 , for fresh and dry matter, respectively. However, increasing the air temperature by up to $4.0{ }^{\circ} \mathrm{C}$ (scenario RCP8.5) may result in a reduction in yield of up to $15 \%$ and $13.5 \%$ by 2060 for fresh and dry matter, respectively.

\section{Acknowledgements}

The authors would like to thank the Research Support Foundation of Alagoas State (FAPEAL) and the Coordination for the Improvement of Higher Education Personnel (CAPES) for making scholarships available. 


\section{Compliance with Ethical Standards}

Author contributions: Conceptualization: LRS, GBL, JAB; Data curation: LRS, JAB, JLS; Formal analysis: LRS, ALC, IDM, $\mathrm{GBL}, \mathrm{GBL}$, JLS; Investigation: LRS, ALC, IDM, GBL, GBL, JLS; Methodology: $A L C, G B L, G B L, J L S, J A B$; Project administration: GBL, JAB, ALC; Resources: GBL, IT; Software: ALC; Supervision: ALC, GBL; Validation: GBL, GBL, JAB, JLS, IT; Visualization: LRS, ALC, GBL; Writing - original draft: LRS, ALC, IDM, GBL; Writing - review \& editing: GLB, JLS, IT, JAB.

Conflict of interest: The authors declare no conflict of interest.

Financing source: This work has no financial funding.

\section{Literature Cited}

Agrolink. Nordeste pesquisa cana mais produtiva. https://www. agrolink.com.br/noticias/nordeste-pesquisa-cana-maisprodutiva_75554.html. 17 Feb. 2019.

Allen, R. G.; Pereira, L. S.; Raes, D.; Smith, M. Crop evapotranspiration - guidelines for computing crop water requirements. Roma: FAO, 1988. (FAO. Irrigation and Drainage Paper, 56). 300p.

Almeida, A. C. S.; Souza, J. L.; Teodoro, I.; Barbosa, G. V. S.; Moura Filho, G.; Ferreira Junior, R. A. Desenvolvimento vegetativo e produção de variedades de cana-de-açúcar em relação à disponibilidade hídrica e unidades térmicas. Ciência e Agrotecnologia, v.32, n.5, p.1441-1448, 2008. https://doi.org/10.1590/S141370542008000500013.

Boschiero, B. N.; Castro, S. G. Q.; Rocha, A. E. Q.; Franco, H. C. J.; Carvalho, J. L. N.; Soriano, H. L.; Santos, J. A.; Bressiani, J. A.; Kölln, O. T. Biomass production and nutrient removal of energy cane genotypes in northeastern Brazil. Crop Science, v.59, n.1, p.379-391, 2019. https://doi.org/10.2135/cropsci2018.07.0458.

Carvalho A. L.; Souza, J. L; Almeida, A. C. S.; Lyra, G. B.; Lyra, G. B.; Teodoro, I.; Ferreira Junior, R. A.; Magalhães, I. D.; Santos, L. $R$. Sugarcane productivity simulation under different planting times by the DSSAT/CANEGRO model in Alagoas, Brazil. Emirates Journal of Food and Agriculture, v.30, n.3, p.190-198, 2017. https://doi.org/10.9755/ejfa.2018.v30.i3.1640.

Carvalho, A. L.; Menezes, R. S. C.; Nóbrega, R. S.; Pinto, A. S.; Ometto, J. P. H. B.; Randow, C. V.; Giarolla, A. Impact of climate changes on potential sugarcane yield in Pernambuco, northeastern region of Brazil. Renewable Energy, v.78, p.26-34, 2015. https://doi. org/10.1016/j.renene.2014.12.023.

Caversan, A. S. Modelo matemático para o planejamento do plantio e colheita da cana-de-açúcar e da cana-energia. Bauru: Universidade Estadual Paulista "Júlio de Mesquita Filho", 2017. 58 p. Master's Dissertation. https://repositorio.unesp.br/ handle/11449/152364. 16 Nov. 2020.

Guimarães, S. O.; Costa, A. A.; Vasconcelos Júnior, F. C.; Silva, E. M.; Sales, D. C.; Araujo Junior, L. M.; Souza, S. G. Projeções de mudanças climáticas sobre o nordeste brasileiro dos modelos do CMIP5 e do CORDEX. Revista Brasileira de Meteorologia, v.31, n.3, p.337-365, 2016. https://doi.org/10.1590/0102778631320150150 .
Jones, M. R.; Singels, A. Refining the Canegro model for improved simulation of climate change impacts on sugarcane. European Journal of Agronomy, v.100, p.76-86, 2018. https://doi. org/10.1016/j.eja.2017.12.009.

Jones, M. R.; Singels, A.; Ruane, A. C. Simulated impacts of climate change on water use and yield of irrigated sugarcane in South Africa. Agricultural Systems, v.139, p.260-270, 2015. https://doi. org/10.1016/j.agsy.2015.07.007.

Marin, F. R.; Jones, J. W.; Royce, F.; Suguitani, C.; Donzeli, J. L.; Pallone Filho, W. J.; Nassif, D. S. P. Parameterization and evaluation of predictions of DSSAT/CANEGRO for sugarcane Brazilian production systems. Agronomy Journal, v.103, n.2, p.100-110, 2011. https://doi.org/10.2134/agronj2010.0302.

Marin, F. R.; Jones, J. W.; Singels, A.; Royce, F.; Assad, E. D.; Pellegrino, G. Q.; Justino, F. Climate change impacts on sugarcane attainable yield in southern Brazil. Climatic Change, v.117, p.227-239, 2013. https://doi.org/10.1007/s10584-012-0561-y.

Marin, F. R.; Pellegrino, G. Q.; Assad, E. D.; Pinto, H. S.; Zullo Junior, J. Cana de açúcar. In: Monteiro, J. E. B. A. (Ed.). Agrometeorologia dos cultivos: o fator meteorológico na produção agrícola. Brasília: INMET, 2009. p. 111-130.

Marin, F. R.; Thorburn, P.; Nassif, D. S. P.; Costa, L. G. Sugarcane model intercomparison: Structural differences and uncertainties under current and potential future climates. Environmental Modelling \& Software, v.72, p.372-386, 2015. https://doi.org/10.1016/j. envsoft.2015.02.019.

Matsuoka, S.; Bressiani, J. A.; Maccheroni, W.; Fouto, I. Bioenergia da Cana. In: Santos, F.; Borém, A.; Caldas, C. (Eds.). Cana-de-açúcar: bioenergia, açúcar e álcool. 2.ed. Viçosa: UFV, 2012. p.487-517.

Matsuoka, S.; Kennedy, A. J.; Santos, E. G. D.; Tomazela, A. L.; Rubio, L. C. S. Energy cane: Its concept, development, characteristics, and prospects. Advances in Botany, v.2014, e 597275, 2014. https://doi.org/10.1155/2014/597275.

Nassif, D. S. P.; Marin, F. R.; Pallone Filho, W. J.; Resende, R. S.; Pellegrino, G. Q. Parametrização e avaliação do modelo DSSAT/ Canegro para variedades brasileiras de cana-de-açúcar. Pesquisa Agropecuária Brasileira, v.47, n.3, p.311-318, 2012. https://doi. org/10.1590/S0100-204X2012000300001.

Oliveira, L. A. Manejo da irrigação no cultivo da cana-de-açúcar e milho sob cenários futuros: aplicação dos modelos DSSAT/ CANEGRO e CERES-MAIZE. Piracicaba: ESALQ, 2015. 93p. Master's Dissertation. https://doi.org/10.11606/D.11.2015.tde22042015-172932.

Pinto, H. M. S.; Viana, M. S.; Costa, L. G.; Marin, F. R. Produtividade de cana-de-açúcar no Estado de São Paulo baseada em simulações multimodelos e mudanças climáticas. Revista Brasileira de Agrometeorologia, v.26, n.1, p.11-20, 2018. https://doi. org/10.31062/agrom.v26i1.26300.

Sarmento, P. L. V. S. Produção de cana-energia e suas características energéticas em condição tropical. Rio Largo: Universidade Federal de Alagoas, 2019. 103p. Doctoral Thesis. http://www. repositorio.ufal.br/jspui/handle/riufal/6487. 05 Nov. 2020.

Silva, C. R. P. Desenvolvimento inicial do eucalipto e fertilidade do solo após aplicação de lodo de esgoto e composto de lodo. Botucatu: Unesp, 2019. 179 p. Master's Dissertation. https:// repositorio.unesp.br/handle/11449/191692. 11 Nov. 2020. 
Silva, R. F. Calibração do modelo DSSAT/CANEGRO para a cana-deaçúcar e seu uso para a avaliação do impacto das mudanças climáticas. Viçosa: UFV, 2012. 56p. Master's Dissertation. https:// locus.ufv.br//handle/123456789/5251. 07 Dec. 2020.

Silva, S. I. S. Biomassa para a geração de energia: Eucalipto, canaenergia, e bagaço de cana-de-açúcar. João Pessoa: Universidade Federal da Paraíba, 2016. 46p. Undergraduate Thesis. https:// repositorio.ufpb.br/jspui/handle/123456789/1518. 16 Nov. 2020.
Singels, A.; Jones, M.; Van Der Berg, M. DSSAT v.4.5 DSSAT/CANEGRO: sugarcane plant module: scientific documentation. Mount Edgecombe: International Consortium for Sugarcane Modeling: South African Sugarcane Research Institute, 2008. 34p. https://sasri. sasa.org.za/agronomy/icsm/documents/DSSAT\%20Canegro\%20 SCIENTIFIC\%20documentation_20081215.pdf. 28 Oct. 2020.

Sousa, L. F.; Santos, J. G. D.; Alexandrino, E.; Maurício, R. M.; Martins, A. D.; Sousa, J. T. L. Método prático e eficiente para estimar a área foliar de gramíneas forrageiras tropicais. Archivos de Zootecnia, v.64, n.245, p.83-85, 2015. https://doi.org/10.21071/az.v64i245.380. 